PONTIFÍCIA UNIVERSIDADE CATÓLICA DO RIO DE JANEIRO

Comportamento do consumidor no paradoxo de recuperação de serviços

\author{
Lívia Tostes E. de Oliveira
}

Trabalho de Conclusão de CuRso

Centro de CIÊnCIAS Sociais - CCS

DEPARTAMENTO DE ADMINISTRAÇÃO

Graduação em Administração de Empresas 
Lívia Tostes E. de Oliveira

\section{Comportamento do consumidor no paradoxo de recuperação de serviços}

Trabalho de Conclusão de Curso

Trabalho de Conclusão de Curso, apresentado ao programa de graduação em Administração da PUC-Rio como requisito parcial para a obtenção do título de graduação em Administração.

Orientador: Marcus Wilcox Hemais

Rio de Janeiro

Dezembro de 2020. 


\section{Agradecimentos}

Nos últimos quatro anos, não foram poucos os momentos de privação em prol dos estudos. Quem me conhece o mínimo sabe o quanto me dediquei à minha graduação. Chega o final deste ciclo e, como não poderia ser diferente, devo os meus sinceros agradecimentos às pessoas que, de alguma forma, dele participaram e permitiram essa conquista que agora está tão próxima.

Apenas para começar, agradeço aos meus mestres Pontifícia Universidade Católica do Rio de Janeiro, fontes de saber inesgotável, responsáveis por grande parte do conhecimento profissional que disponho hoje. Em especial, agradeço à professora Alessandra Baiocchi, que me apresentou ao Marketing e lecionou a maioria das minhas disciplinas da área. Devo também especial agradecimento ao meu orientador Marcus Hemais, não só por sua atenção e competência, mas também por ter me aceitado como orientanda sem ao menos me conhecer pessoalmente ou ter sido meu professor antes.

Nada disso teria sido possível sem a minha querida família, que esteve sempre ao meu lado nessa jornada para comemorar as pequenas e grandes vitórias, bem como para apoiar, superar e alegrar os momentos difíceis. Como não há espaço para citar todos neste momento, reservo o meu agradecimento especial e gratidão sem fim aos meus pais Luciana e Ricardo, que, desde que nasci, dedicaram-se à minha criação, ensinaram-me os valores básicos da vida e se preocuparam com os meus estudos, sendo os principais incentivadores para eu sempre ir além.

À minha irmã Luísa, devo especiais agradecimentos. Obrigada por ser minha ouvinte diária, por tornar meus dias mais leves, por ter me apoiado durante a elaboração desta monografia quando precisei de incentivo e, principalmente, por me fazer sentir esta forma de amor tão pura.

Por fim, agradeço a todos os meus amigos, que compreenderam os diversos momentos em que eu não pude estar presente ao longo dos quatro anos do curso. Agradecimento especial à minha colega de faculdade e amiga para toda a vida, Juliana, pelo incentivo constante e presença em toda essa jornada. 


\section{Resumo}

OLIVEIRA, Lívia. Comportamento do consumidor no paradoxo de recuperação de serviços. Rio de Janeiro, 2020. 35 p. Trabalho de Conclusão de Curso - Departamento de Administração. Pontifícia Universidade Católica do Rio de Janeiro.

O presente estudo visa analisar o efeito que o tipo de resolução a uma falha de serviço no setor do e-commerce provoca na satisfação de consumidores, buscando, desta feita, identificar se o paradoxo de serviços existe e as razões de sua existência. A pesquisa foi realizada com homens e mulheres, moradores do estado do Rio de Janeiro, entre 21 e 61 anos. Para isso, foi elaborada uma pesquisa exploratória de cunho qualitativo pautado pelo uso da técnica projetiva. Objetivou-se, dessa forma, analisar os sentimentos dos consumidores diante de soluções de empresas após uma falha no serviço. Após a análise, concluiu-se que os consumidores tendem a ficar insatisfeitos e inconformados com soluções já esperadas, não sendo devidamente recompensado para voltar aos negócios. Por fim, algumas ações foram listadas para redirecionar as ações da empresa.

Palavras- chave

Paradoxo de recuperação de serviços; satisfação; e-commerce marketing

\section{Abstract}

OLIVEIRA, Lívia. Consumer behavior in the service recovery paradox. Rio de Janeiro, 2020. 35 p. Trabalho de Conclusão de Curso - Departamento de Administração. Pontifícia Universidade Católica do Rio de Janeiro.

This study aims to analyze the effect on consumer satisfaction given different types of resolutions to e-commerce service failure. Seeking, to identify whether the services paradox exists and the reasons for its existence. The research was carried out with men and women, residents of the state of Rio de Janeiro, between 21 and 61 years old. For this, an exploratory research of qualitative nature based on a projective technique was elaborated. In this way, the goal was to analyze the feelings of consumers when facing company solutions after a service failure. After the analysis, it was concluded that consumers tend to be dissatisfied with solutions already expected, not being properly rewarded enough to continue buying from the establishment. Finally, some actions were listed to redirect the company's attitude.

\section{Key-words}


Service recovery paradox; satisfaction; e-commerce marketing 


\section{Sumário}

1. O tema e o problema de estudo 1

1.1. Introdução ao tema e ao problema do estudo 1

1.2. Objetivo do estudo 2

1.3. Delimitação e foco do estudo 2

1.4. Justificativa e relevância do estudo 3

2. Referencial teórico 4

2.1. Marketing de Serviços 4

2.2. Satisfação e processo de fidelização do cliente 5

2.3. Recuperação de clientes e o paradoxo

3. Metodologia 9

3.1. Tipo de pesquisa 9

3.2. Seleção dos entrevistados 10

3.3. Coleta dos dados 11

3.4. Análise dos dados 12

3.5. Limitações da metodologia 12

4. Apresentação e análise dos resultados 14

4.1. Situação 1: a empresa vai além 14

4.2. Situação 2: a empresa faz o necessário 15

4.3. Situação 3: a empresa deixa a desejar 17

4.4. As três situações: uma análise geral 18

5 . Considerações finais 1

5.1. Implicações gerenciais 2

5.2. Sugestões e recomendações para futuros estudos 3

6. Referências Bibliográficas 4 
Apêndice 1 - Formulário de entrevistas

Apêndice 2 - Respostas dos entrevistados

\section{Lista de Tabelas}

Tabela 1: Dados dos entrevistados ........................................................ 10

Tabela 2: Resumo da pesquisa de campo .............................................. 1 


\section{O tema e o problema de estudo}

O presente capítulo volta-se à apresentação do tema a ser desenvolvido no trabalho, contextualizando, em linhas gerais, o assunto que será aprofundado. Para tanto, de início, será abordado o problema que ensejou o estudo, destacando-se a relevância da pesquisa para o setor de Marketing. Também serão traçados os objetivos do trabalho e as hipóteses que se pretende confirmar.

\subsection{Introdução ao tema e ao problema do estudo}

Face a um cenário de mercados competitivos, em que o setor de serviços ocupa uma posição importante na economia, as organizações reconhecem a necessidade de conquistar e manter clientes para garantir a sua sobrevivência (TINOCO; RIBEIRO, 2007). Cada vez mais, as vendas pontuais perdem importância, dando lugar à necessidade de fidelização dos clientes e foco nas relações de longa duração. Dessa forma, para garantir o crescimento do negócio, é fundamental o entendimento de conceitos como fidelização de clientes, satisfação de consumidores e recuperação dos serviços.

Nessa ambiência, destaca-se o que se entende por paradoxo de recuperação de serviços. Trata-se de uma teoria apresentada pela primeira vez em 1992 por McCollough e Bharadwaj. Tal paradoxo consiste na proposição de que uma recuperação de serviços eficaz proporciona maior satisfação para o cliente do que no caso de não ocorrer falha alguma. Portanto, clientes que passam por uma falha de serviço bem resolvida tendem a ter maior inclinação a realizar compras futuras do que clientes sem problemas prévios.

A teoria é importante do ponto de vista do Marketing, mas não existe consenso na doutrina a respeito de sua existência de fato. Existem estudos empíricos que obtiveram resultados divergentes quanto à existência do paradoxo de recuperação de clientes: alguns confirmam a hipótese com resultados significativos (SOARES; PROENA; KANNAN, 2014), outros refutam sua aplicabilidade gerencial como Michel e Meuter (2008). Por tal razão, mostra-se necessário aumentar o número de estudos na área a fim de averiguar se o 
paradoxo da recuperação de clientes é legítimo ou apenas uma eventual coincidência entre pesquisas feitas com métodos e variáveis diferentes.

Nessa esteira, esta pesquisa busca elucidar as seguintes indagações: 0 paradoxo de recuperação de serviços existe? Se existe, quais fatores influenciam uma maior ou menor fidelização do cliente que sofreu uma falha na prestação do serviço contratado?

\subsection{Objetivo do estudo}

Como exposto no tópico antecedente, a fidelização de clientes é ponto crucial no sucesso dos negócios em geral. Diante disso, é importante identificar o que contribui para a maior satisfação dos consumidores e, por conseguinte, o seu regresso. Um aspecto que deve ser considerado neste mister é o estudo do comportamento do consumidor diante de uma falha no serviço. No entanto, a literatura de Marketing parece carecer de estudos mais abrangentes e integrados sobre essa temática.

O paradoxo de recuperação de serviços é uma teoria que trabalha nessa direção: ensina a contradição que existe no fato de um cliente estar mais propenso a realizar novos negócios com uma empresa, quando teve um problema na prestação de serviço anteriormente contratado, cuja solução foi bem sucedida. Portanto, o paradoxo, se bem estudado, pode contribuir para a tão sonhada construção de uma clientela fiel.

Acontece que, como já exposto, não existe um consenso doutrinário acerca da existência, em sentido genérico, do referido paradoxo. Por tal razão, o presente estudo destina-se a analisar o efeito que o tipo de resolução a uma falha de serviço provoca na satisfação de consumidores, buscando, desta feita, identificar se o paradoxo realmente existe e as razões de sua existência.

\subsection{Delimitação e foco do estudo}

O trabalho abordará o paradoxo de recuperação do serviço - considerando a hipótese de que ele existe - sob o enfoque do cliente, a fim de identificar a sua visão sobre como deve ser a postura da empresa diante de uma falha no produto ou no serviço para que ele volte a fazer negócios com ela. Não se pretende, assim, fazer um estudo de um produto específico (como um modelo de carro ou de aspirador de pó), mas, sim, verificar os fatores que contribuem para 
uma falha trazer frutos à empresa no setor do varejo, mais especificamente no $e$ commerce de marcas que sejam também marketplace.

Dessa forma, é preciso centrar os olhares no cliente para saber os seus sentimentos e expectativas diante de um produto defeituoso, e as razões que o levam a voltar a realizar negócios com uma empresa com a qual teve problemas ao invés de simplesmente escolher outra concorrente. Para isso, é necessário analisá-lo ainda dentro de um contexto empresarial com objetivo de verificar qual é a melhor maneira de a empresa criar oportunidade diante de uma falha que, em tese - e somente em tese - a faria perder um cliente.

Outro ponto que será tratado transcende a percepção subjetiva do cliente para alcançar o perfil objetivo do consumidor, a partir do cruzamento de dados, especificamente de indicadores como sexo, idade, profissão e condição socioeconômica - e o seu nível de satisfação diante de uma falha no serviço bem resolvida, buscando traçar a probabilidade de determinado perfil de consumidor persistir nas relações com a empresa em futuras ocasiões.

Tal ângulo de análise - voltado ao consumidor - se mostra interessante e importante porque procura identificar os motivos pelos quais determinadas pessoas fazem o paradoxo ser legítimo e compreender em que variáveis são mais propícias para ele ocorrer. Assim, será possível traçar elementos que subsidiem a elaboração de um planejamento empresarial eficaz para lidar com questões relativas ao atendimento do consumidor no pós-venda.

\subsection{Justificativa e relevância do estudo}

As respostas que esse estudo pretende alcançar serão de interesse para as empresas que, diante da concorrência cada vez mais acirrada, precisam entender o universo que os cerca em aspectos que transcendem seu próprio mundo corporativo. Afinal, seus clientes estão, cada vez mais, envolvidos em uma rede de elementos sociais, psicológicos, ambientais, políticos e tecnológicos que, simultaneamente, interagem para definir sua decisão de consumo.

Ademais, o resultado da pesquisa também contribuirá para a literatura de Marketing, que amarga a falta de consenso quanto à existência do paradoxo de recuperação de serviços, como mencionado anteriormente. 


\section{Referencial Teórico}

Neste capítulo, são apresentados e discutidos aspectos conceituais e estudos relacionados ao tema e estudo em investigação e que servirão de base para a análise realizada.

Esta seção está dividida em três partes que abordam, respectivamente, a questão da importância do marketing de serviços para contextualizar o problema de estudo sobre o comportamento do consumidor perante uma falha no serviço, o conceito de satisfação e fidelização do cliente, segundo Kotler (2012), e suas implicações para o setor de varejo. $\mathrm{Na}$ terceira seção, discutem-se as perspectivas de nomeados autores sobre o processo de recuperação de cliente, com foco na perspectiva da existência do paradoxo.

\subsection{Marketing de Serviços}

A relevância do marketing de serviços está relacionada à importância econômica dos serviços nas economias dos países. Além disso, à medida que se limitam as possibilidades de diferenciação de produtos, devido à saturação dos mercados, as organizações encontram-se obrigadas a desenvolver vantagens competitivas centradas na oferta ampliada de serviços.

A diferenciação entre bens e serviços nem sempre é absolutamente compreensível, segundo Hoffman e Bateson (2003). De fato, é complexo recordar um exemplo de um bem puro ou de um serviço puro. Um bem puro provocaria que os benefícios recebidos pelo cliente não contivessem elementos fornecidos por serviço e vice-versa. Porém, na prática, ambos são complementares. Dessa forma, diversos serviços contêm elementos de bens tangíveis, como o cardápio em restaurante, e a maioria dos bens oferecem pelo menos um serviço, como o de entrega ou de venda. Assim, fica claro verificar que os bens estão associados a objetos físicos enquanto os serviços às ações.

O composto de marketing, conhecido também como mix de marketing, é um conjunto de ferramentas de marketing que a empresa utiliza para perseguir seus objetivos de marketing no mercado-alvo (KOTLER, 2000). Assim, tal composto é formado por produto, preço, praça e promoção. Porém, a evolução 
constante do mercado fez com que a atenção dos profissionais de marketing ampliasse e adaptasse três novos conceitos para responder aos novos rumos do mercado moderno: pessoas, ambiente físico e processos (LOVELOCK, 2006). Dessa forma, os profissionais de marketing precisam desenvolver a combinação correta desses 7P's para atender ao cliente-alvo.

Zeithaml e Bitner (2003) afirmam que os três novos elementos do composto de marketing de serviços estão incluídos no composto de marketing tradicional como elementos separados por estarem dentro do controle da empresa, e qualquer um deles, ou mesmo todos, podem influenciar a decisão inicial do cliente de comprar um serviço, assim como o nível de satisfação de um cliente e suas decisões de recompra (ZEITHAML; BITNER, 2003).

Portanto, é assinalada a presença do Marketing de Serviços em todos os pilares da economia, o que demonstra uma real importância de estudá-lo profundamente.

\subsection{Satisfação e processo de fidelização do cliente}

O interesse pela satisfação e fidelização do cliente é amplamente verificado no meio acadêmico e nas organizações em geral. Isso se justifica pelo acirramento da concorrência com o qual os produtores de bens e de serviços crescentemente se deparam, e a necessária rapidez em suas decisões voltadas para evitar a perda de clientes. A satisfação é um dos principais elementos capazes de fidelizar um cliente. Assim, as empresas devem buscar a satisfação como forma de estreitar a relação com seus clientes (KOTLER; KELLER, 2006).

Para as organizações, entre os inúmeros benefícios recebidos por nutrir clientes altamente satisfeitos estão: menor elasticidade de preços, distanciamentos dos clientes de ofertas da concorrência, menores custos de transações futuras, custos de falha reduzidos, menor custo para atrair novos clientes, além da melhoria da reputação da empresa e, por conseguinte, maior lealdade dos clientes (FORNELL, 1992).

Consoante a Kotler e Keller (2006), a satisfação é um sentimento de prazer ou decepção que resulta da comparação entre o desempenho percebido de um produto e as expectativas do comprador. Caso o desempenho alcance as expectativas, o cliente ficará satisfeito e, caso contrário, ficará insatisfeito. Além disso, se o desempenho superar as expectativas do cliente, este ficará altamente satisfeito. 
Já para Fornell et al. (1996), satisfação é um índice que capta experiências passadas e preocupações futuras do cliente. Nesse modelo, os autores definem a satisfação global como sendo composta por três elementos: (i) a qualidade percebida, que é a avaliação pelo cliente do desempenho do produto, em uma experiência de consumo recente; (ii) o valor percebido, que diz respeito ao nível de qualidade relativo ao preço pago, com isso, um componente de preço é incluído na definição de satisfação global e (iii) as expectativas do cliente, que representam tanto as expectativas prévias ao momento de consumo em relação à oferta, como uma expectativa futura da habilidade do fornecedor em entregar qualidade.

Ainda, para Oliver (1997, p. 13), "satisfação é a resposta à completude do consumidor. É o julgamento de que uma característica do produto/serviço, ou o produto/serviço em si, ofereceu (ou está oferecendo) um nível prazeroso de completude relativa ao consumo, incluindo níveis maiores ou menores de completude".

Nessa concepção, as empresas devem elaborar maneiras de desenvolver vínculos fortes com os clientes, objetivando fidelizá-los. Existe um entendimento que, quanto maior a satisfação do cliente, maior a chance de fidelização deste à marca e, consequentemente, maior probabilidade de se ter uma boa reputação no mercado e obter futuras receitas. Assim, no que tange à definição de fidelização, podemos dizer que é um comprometimento profundo em consistentemente recomprar ou preferir um produto ou serviço no futuro, apesar de influências situacionais e de esforços de marketing que busquem levar o consumidor a trocar de fornecedor (OLIVER, 1999).

Para isso, as empresas devem investir em: (i) criar produtos e experiências superiores para o mercado-alvo; (ii) engajar todos os departamentos da empresa no planejamento e gerenciamento do processo de satisfação e retenção de clientes; (iii) integrar a voz do cliente para capturar suas necessidades ou exigências declaradas e não declaradas em todas decisões organizacionais; (iv) organizar e disponibilizar um banco de dados com informações sobre necessidades, preferências, contatos, frequência de compras e satisfação do cliente; (v) facilitar o acesso dos clientes ao departamento apropriado da empresa para que expressem suas necessidades, percepções e reclamações; (vi) avaliar o potencial dos programas de frequência de compras e programas de filiação; e (vii) implementar programas de incentivo para recompensar os funcionários que se destacarem (KOTLER; KELLER, 2006). 
Nessa ambiência, a qualidade total pode ser uns dos segredos para se criar valor e satisfazer o cliente, assim como para obter a lucratividade da empresa. O cliente lucrativo seria uma pessoa, a própria família ou a organização, que, ao longo do tempo, poderá render fluxos de receita que excedem por uma margem aceitável o fluxo dos custos de atração deste cliente (KOTLER; KELLER, 2006). Além disso, a qualidade em serviço é o ponto central na avaliação do cliente, portanto a empresa que sempre almeja a retenção e fidelização do cliente deve oferecer serviços que tenham esse potencial (HOFFMAN; BATESON, 2003).

\subsection{Recuperação de clientes e o paradoxo}

Diferentes pesquisas têm sido realizadas com o objetivo de entender melhor o comportamento do consumidor de serviços diante de situações imperfeitas (HEMAIS; CASOTTI, 2014), durante a prestação de serviços, e como as empresas responsáveis pelos erros trabalham quando o cliente apresenta uma reclamação. As conclusões de tais pesquisas validam que situações de insatisfação podem gerar sérias consequências para as empresas. Esse obstáculo pode ser evitado quando a organização está preocupada em ouvir as reclamações dos clientes e resolver cada situação de modo a proporcionar a satisfação absoluta e a consequente recuperação deste cliente.

Para Grönroos (1995), o nível de qualidade percebido por um cliente com relação a um serviço é determinado pela diferença entre a qualidade esperada antes de receber o serviço e a qualidade experimentada durante e após a sua prestação. Quando o serviço prestado não atinge o nível de expectativas do cliente, há um problema de qualidade ou uma falha na prestação do serviço. Daí decorre que a compreensão da origem e da natureza das falhas é fundamental para a gestão da qualidade em empresas de serviço.

Pesquisas mostraram que a maioria das pessoas não reclamam de um serviço, principalmente se acham que a reclamação não surtirá efeito (KOTLER; KELLER, 2006). Desconhecendo essa informação, diversas empresas ainda acreditam que, se o cliente não reclama, seu serviço está satisfatório. Porém, diversas vezes, o cliente está quieto, aguardando uma oportunidade para mudar para o concorrente (LOVELOCK, 2006). Dessa forma, se os clientes não reclamam, a empresa desconhece maneiras que possam recuperar o cliente insatisfeito. Assim, clientes que reclamam dão à empresa a chance de corrigir 
problemas que talvez ela nem saiba que tem, restaurando o relacionamento com o reclamante e melhorando situações futuras.

Uma recuperação eficaz requer procedimentos sérios para resolver problemas e lidar com clientes decepcionados. É importante que a empresa reconheça a sensibilidade da fidelidade de um cliente. Dessa forma, é fundamental que a empresa tenha estratégias para lidar com isso, pois um único problema no serviço pode ser decisivo na escolha da próxima compra.

Quando as reclamações são resolvidas de maneira satisfatória, os clientes ficam mais propensos a permanecer fiéis (LOVELOCK, 2006). Lovelock (2006) afirma que o tratamento de reclamações deve ser considerado como um centro de lucro, e não de custo. Isso porque, quando um cliente insatisfeito desiste de realizar a reclamação, a empresa perde mais do que o valor da próxima compra; perde o fluxo de lucro de longo prazo do cliente. Entretanto, organizações ainda necessitam aderir ao conceito de que vale a pena elaborados investimentos nestas situações.

Clientes que sofreram uma falha de serviço resolvida de modo satisfatório diversas vezes estão mais satisfeitos do que outros que não tiveram nenhum problema (MATOS; HENRIQUE; ROSSI, 2007). Assim, se constitui o paradoxo de recuperação de serviços. Paradoxo porque se esperava que 0 cliente sem falhas fosse mais propício à satisfação do que o que obteve falhas importunas. De fato, a existência do paradoxo é condicionada a alguns aspectos do serviço, como a gravidade, incidência, entre outros. Nem sempre é possível restaurar completamente o cliente, como no caso de as fotos de um casamento não terem ficado boas, por exemplo. Para Michel Hargrove (2000), a recuperação de serviço é transformar uma falha de serviço em uma oportunidade que você nunca desejaria ter tido. 


\section{Metodologia}

O capítulo a seguir discute a metodologia adotada na pesquisa. Assim, pretende informar sobre as diversas decisões acerca da forma como este estudo foi realizado. Ele está dividido em cinco partes. A primeira fala sobre o tipo de pesquisa adotado. A segunda fala sobre o processo de seleção dos entrevistados. A terceira fala sobre a forma de coleta de dados, enquanto a quarta apresenta a maneira como os dados foram analisados. Por fim, na quinta, apresentam-se as limitações da metodologia.

\subsection{Tipo de pesquisa}

Para o presente estudo, foi adotada a pesquisa exploratória, a qual é significativa em qualquer situação da qual o pesquisador não disponha do entendimento suficiente para prosseguir com 0 projeto de pesquisa (MALHOTRA, 2001). Esse tipo de pesquisa tem como propósito definir a natureza do problema reconhecido, sendo o primeiro passo para um estudo futuro mais rigoroso e conclusivo (ZIKMUND, 2006). Faz-se adequada a utilização desse tipo de pesquisa pois, como mencionado anteriormente, a literatura carece de estudos mais aprofundados sobre o paradoxo de recuperação de serviços.

Além disso, é importante ressaltar que a pesquisa é de natureza qualitativa. Esse tipo de pesquisa busca alcançar uma compreensão das razões e motivações subjacentes (MALHOTRA, 2001). A pesquisa qualitativa caracteriza-se por ter um pequeno número de casos que resultam no desenvolvimento de uma compreensão inicial sobre o assunto. Para o presente estudo, é interessante observar cada particularidade apresentada pelo entrevistado, sendo o mais apropriado para a análise.

Portanto, a coleta de dados foi elaborada com o uso da técnica projetiva. Essa metodologia facilita a articulação de pensamentos reprimidos pelo respondente, já que ele "projeta" seus pensamentos a alguém ou alguma coisa, ao invés de si mesmo (HEMAIS; CASOTTI, 2014). Em vez de questionar as opiniões de um entrevistado a respeito de determinado assunto, essa técnica 
possibilita que os questionamentos sejam formulados com base no que ele acha que outro indivíduo faria em determinada situação. Deste modo, possibilita maior liberdade para o entrevistado responder o que realmente pensa ou faria, já que não está falando de si próprio diretamente (WILL; EADIE; MacASKILL, 1996).

A razão para o uso de tal método se deve ao entrevistado possivelmente não querer expor sua real personalidade, visto que são situações que expõem seus valores e atitudes. Para o presente estudo, é pertinente o uso dessa técnica por se imaginar que o consumidor pode não ter passado por esse tipo de situação até o momento.

\subsection{Seleção dos entrevistados}

Foram entrevistados 12 consumidores de e-commerce, sendo seis mulheres e seis homens, moradores do estado do Rio de Janeiro, com idades diversas.

Os respondentes foram selecionados por acessibilidade, ou seja, foram entrevistadas pessoas do ciclo mais próximo da pesquisadora, que pudessem agregar respostas significativas para a pesquisa. Dessa forma, foram entrevistados estudantes da PUC-Rio, familiares e amigos que tiveram experiência de fazer compras pela internet e que puderam refletir seus sentimentos nas situações da técnica projetiva.

É importante ressaltar que não foram considerados dados demográficos e socioeconômicos para a análise.

Tabela 1: Dados dos entrevistados

\begin{tabular}{|c|l|c|l|}
\hline$N^{\circ}$ & Nome & Idade & Profissão \\
\hline 1 & Luciana & 54 & Médica \\
\hline 2 & Marilda & 61 & Aposentada \\
\hline 3 & Patrícia & 52 & Psicóloga \\
\hline 4 & Luísa & 27 & Servidora pública \\
\hline 5 & Juliana & 22 & Estudante \\
\hline 6 & Jéssica & 21 & Estudante \\
\hline 7 & Emmanuel & 25 & Estudante \\
\hline 8 & Victor & 25 & Estudante \\
\hline 9 & Paulo & 28 & Advogado \\
\hline 10 & Diego & 22 & Estudante \\
\hline 11 & Lucas & 23 & Professor \\
\hline 12 & Pedro & 24 & Administrador \\
\hline
\end{tabular}


Fonte: Elaboração própria (2020).

\subsection{Coleta dos dados}

A coleta de dados foi realizada por meio de dois formulários (disponíveis no Apêndice 1), um destinado a entrevistas com homens e outro com mulheres, mudando apenas o nome da pessoa hipotética criada para cada situação. Isso foi feito porque, no estudo de Hemais e Casotti (2014), percebeu-se que os entrevistados davam respostas menos estruturadas quando o nome do consumidor protagonista da situação descrita era do gênero oposto ao dele e, provavelmente, isso ocorria porque era mais difícil para os entrevistados se projetarem como um indivíduo do outro gênero.

Cada formulário abordou três situações relativas a procedimentos de recuperação de clientes diante de uma falha de serviço que as empresas comumente fazem. Entendendo que os consumidores entrevistados poderiam não ter passado por uma situação semelhante por não ter presenciado uma falha, preferiu-se aderir à técnica projetiva. As situações foram elaboradas conforme experiências vivenciadas pela própria pesquisadora. Em cada situação, os entrevistados eram indagados sobre o que achavam da solução oferecida ao personagem, o que empresa poderia ter feito diferente, se o personagem ficou feliz com a solução da empresa e se ele deveria voltar a fazer negócios com a empresa após o ocorrido.

Como preparação para a coleta de dados, foi feito um pré-teste com dois consumidores de produtos de e-commerce (um homem e uma mulher), a fim de verificar dificuldades de entendimento ou se havia palavras que não eram compreendidas pelos entrevistados. Após não ter tido nenhum problema com o entendimento das situações, começaram as entrevistas válidas para a presente pesquisa.

Além disso, cabe ressaltar que as situações foram embaralhadas em cada entrevista para retirar o viés que poderia ser causado caso fosse na ordem da melhor para a pior situação.

Para coletar os dados com os amigos próximos que não eram familiares, foi necessário realizar uma chamada de vídeo por telefone, visto que as entrevistas foram realizadas durante a pandemia do Coronavírus, em outubro e novembro de 2020. 


\subsection{Análise dos dados}

O tratamento dos dados foi feito em duas etapas. Primeiro, os dados foram inseridos em uma tabela comparativa das respostas, com indicação do gênero do entrevistado (homem ou mulher). Após isso, foram assinaladas as falas mais relevantes dos entrevistados com objetivo de identificar divergências ou congruências em cada pergunta.

Posteriormente à organização de dados, iniciou-se a análise dos mesmos, por meio de comparações dos relatos dos entrevistados entre si e com os estudos existentes sobre recuperação de clientes. Isso permitiu identificação de semelhanças e diferenças entre eles, de forma a aprofundar a análise.

\subsection{Limitações da metodologia}

Embora a metodologia aplicada seja apropriada à análise da questão proposta, pode-se dizer que a mesma traz algumas limitações.

A pesquisa exploratória ocasiona um problema relacionado à capacidade de realizar análises fundamentadas em descobertas adquiridas com base em uma pequena amostra, o que pode resultar em conclusões extremamente boas sobre um tema ou extremamente ruins, em vez da situação média (ZIKMUND, 2006).

Além disso, uma das principais limitações atribuídas às técnicas projetivas refere-se ao fato de os resultados poderem revelar mais sobre o seu intérprete do que sobre as motivações do respondente devido a um grau considerável de subjetividade por parte do pesquisador (BOND; RAMSEY, 2010). Essa subjetividade pode levar a uma maior variabilidade na interpretação dos dados, suscitando questionamentos com relação à confiabilidade e a validade das técnicas projetivas. Boddy (2007) menciona que as respostas obtidas por meio destas técnicas possuem considerável consistência, mas a interpretação de tais respostas já não possui tanta. Por serem respostas abertas e específicas para determinada situação, as mesmas podem ser analisadas de forma tendenciosa e influenciadas pelos fatores específicos da situação exposta (CHURCHILL; IACOBUCCI, 2002; DONOGHUE, 2000).

Ademais, é um tipo de pesquisa que acompanha, em sua maioria, o método qualitativo, o qual é de natureza subjetiva, ou seja, a interpretação das descobertas é feita por julgamento e podem ser facilmente influenciadas de acordo com a análise do pesquisador (ZIKMUND, 2006). 
Por fim, ainda cabe ressaltar que o fato de a seleção dos entrevistados ter sido por acessibilidade, ou seja, pessoas conhecidas pela entrevistadora podem ocasionar um viés. 


\section{Apresentação e análise dos resultados}

O capítulo a seguir apresenta a análise dos dados coletados na pesquisa de campo, o qual é dividido em quatro seções. Os primeiros três subtópicos referem-se a cada uma das situações da técnica projetiva as quais apresentam soluções realizadas pelas empresas diante de uma falha de serviço. Em seguida, é apresentada uma visão geral dos principais aspectos analisados pela pesquisa, identificando semelhanças e diferenças no comportamento do respondente em cada situação exposta.

\subsection{Situação 1: a empresa vai além}

A primeira situação demonstra uma solução bem resolvida diante de uma falha do serviço de gestão de estoque de um e-commerce. A solução proposta não apenas encontra uma alternativa para o problema com o estorno, mas também oferece um benefício a mais ao cliente como desculpas pela falha ocorrida.

Diante dessa situação, a opinião dos entrevistados foi unânime em considerar que a solução foi boa, tanto para homens quanto para as mulheres. Analisando o ponto de vista de cada um deles, foi possível perceber que o essencial para que a solução fosse considerada perfeita foi a disponibilidade de um vale de 100 reais para que o mesmo pudesse gastar com o que quisesse na loja, demonstrando preocupação e lamentação pelo ocorrido, como no depoimento abaixo:

Acho excelente. Acho que a partir do momento que eles reconheceram o erro e chegaram numa solução é muito bom. Para mim, quando eu compro roupa eu quero muito um produto, às vezes o estorno não soluciona a minha vida e visão na empresa. A ideia de dar 100 reais é ótima, porque quando ganhamos o bônus dar um ar de preocupação e reconhecimento do erro (22 anos, estudante). 
Quando os respondentes foram indagados sobre o que a empresa poderia ter feito de diferente, as ideias foram divididas. Parte deles entende que não teria nada que a empresa pudesse fazer que seja melhor do que foi feito, enquanto outra parte persistiu na posição de que a empresa deveria ter dado uma perspectiva de mudança em seu controle de estoque e procurado uma peça similar para sanar a necessidade do cliente.

Ademais, houve concordância de todos os entrevistados no momento em que foi perguntado se o cliente hipotético teria ficado feliz com a solução e deveria voltar a fazer negócios com a empresa. Isso mostra que a decisão da empresa de dar um agrado com certeza fideliza os clientes, conforme a declaração abaixo:

Com certeza, porque ele se sentiu valorizado e visto como um consumidor. Se sentiu respeitado como uma pessoa e não como um número de pedido (28 anos, advogado).

Por fim, os respondentes foram questionados se o cliente estivesse em uma situação de querer comprar um produto no qual duas lojas ofereciam qual seria mais provável de ele fechar negócio: com essa empresa que obteve uma falha bem resolvida ou com outra que ele nunca tinha tido problemas. A maioria dos entrevistados informou que faria negócios com a mesma empresa, pois já sabiam que se houvesse um problema, eles têm a garantia de que não terão prejuízo ou dor de cabeça.

Isso corrobora com a teoria do paradoxo de recuperação de clientes explicitado por Matos, Henrique e Rossi (2007). No entanto, foi possível perceber durante as entrevistas quais são as variáveis que afetam esse paradoxo: empresa dar ou não perspectivas de melhora na falha, necessidade do produto específico e identificação com a marca a qual normalmente é praticada por uma comunicação que faça a marca ser "amiga" do consumidor, com principal objetivo de ligar o significado social da marca ao cliente.

\subsection{Situação 2: a empresa faz o necessário}

A segunda situação demonstrada aos entrevistados refere-se a um consumidor que realizou uma compra pelo e-commerce da empresa e o produto entregue estava quebrado. Para solucionar o caso, a empresa informou que o 
cliente deveria postar o produto quebrado nos correios e estornaria o valor no cartão em até duas faturas.

Esse caso apresenta uma ideia de uma empresa que não faz mais do que sua obrigação prevista em lei para seu cliente. Sendo assim, os entrevistados se manifestaram, de forma geral, insatisfeitos com a solução proposta. Isso porque eles: 1) teriam que ir aos correios, para retornar o produto à empresa, perdendo tempo; 2) não teriam o produto que estavam precisando; e 3) o valor pago pelo produto defeituoso só retornará até aproximadamente dois meses após o ocorrido. Nota-se essa insatisfação pelo testemunho a seguir:

\footnotetext{
Acho a solução ruim, se eu fosse a Juliana, eu não iria querer ir ao correio perdendo o tempo. Se o produto veio com defeito, a empresa que tem que buscar o produto com defeito. $O$ movimento de ter que ir ao correio e o reembolso estar condicionado a isso é um absurdo para o cliente (27 anos, servidora pública).
}

No entanto, os respondentes indicaram que a empresa poderia ter agido de forma diferente: solicitado foto do produto para comprovar o ocorrido, se disponibilizado para buscar o produto enquanto levava um novo, efetuando o estorno do valor no mesmo dia da reclamação, entre outros.

Portanto, diante dessa situação, todos os entrevistados disseram que o consumidor hipotético não ficou feliz com a "solução totalmente operacional e distanciada do consumidor" (28 anos, advogado) e a maioria informou que ele não deveria voltar a fazer negócios com a empresa e alguns disseram que apenas em casos de necessidades extremas ele poderia voltar. Isso confirma a tese de Lovelock (2006), de que quando as reclamações são resolvidas de maneira satisfatória, os clientes ficam mais propensos a permanecer fiéis e a recíproca se mostra verdadeira.

Além disso, pelo fato de não ter existido a recuperação efetiva do cliente, é verossímil afirmar que, consequentemente, não houve paradoxo de recuperação de serviço, uma vez que o cliente não irá voltar a fazer negócios com a empresa.

A pesquisa demonstra o quanto o consumidor gosta de se sentir valorizado e que isso é um fator decisivo para a recuperação do serviço. Nos dias atuais, já não basta ter uma solução para o problema, mas sim a melhor solução possível para o cliente se sentir cuidado pela empresa e, assim, seguro para os próximos negócios. Podemos identificar isso no depoimento de um entrevistado: 
Ela poderia ter enviado o mesmo produto em perfeitas condições junto a um brinde com o mesmo tema de cozinha... alguma colher, algo assim... (21 anos, estudante).

Esses achados corroboram a relevância do "P" de processos dentre os 7P's do Marketing de Serviços. Conforme Zeithaml e Bitner (2003) atestam, este é um elemento separado, por estar dentro do controle da empresa, e pode influenciar a decisão inicial do cliente de comprar um serviço, assim como o nível de satisfação de um cliente e suas decisões de recompra.

\subsection{Situação 3: a empresa deixa a desejar}

O terceiro caso apresentado aos entrevistados relatou a história de um consumidor que realizou a compra de um produto por meio de um marketplace e o produto não chegou no tempo estipulado. Quando ele entrou em contato com a empresa para saber o que aconteceu com o produto e comunicar a demora, a empresa o informou que ele deveria entrar em contato com a empresa que realizou a venda, por se tratar de um marketplace.

Diante desse contexto, todos os entrevistados apresentaram sentimentos de aborrecimento e desagrado com a solução oferecida pela empresa. Por unanimidade, os respondentes expuseram que a empresa deveria ter intermediado e entrado em contato com o vendedor, pois mesmo sendo um marketplace, se o nome da empresa está estampado no momento de realizar a compra, ela tem responsabilidade pelo cliente também:

Ruim, péssima solução. A partir do momento que a Claudia comprou o produto na plataforma digital da empresa, mesmo que seja um marketplace ambas são responsáveis pela venda. Não pode transferir a responsabilidade para outra empresa apenas (27 anos, servidora pública).

Além disso, foi ressaltado ainda a relevância que a demonstração de preocupação tem na imagem que a empresa passa para o cliente. No depoimento abaixo, pode -se notar a indignação do cliente com a solução oferecida:

(A empresa) Deveria se mostrar mais preocupada com o que aconteceu com uma abordagem mais amigável, tipo "Você 
pode entrar em contato clicando nesse link, mas se não te responderem em $X$ tempo você responde esse e-mail que entraremos em contato internamente" ( 28 anos, advogado).

Portanto, os entrevistados concluíram que o cliente hipotético com certeza não ficou feliz e que o mesmo não deveria voltar a fazer negócios com a empresa, a não ser que fosse muito necessário "porque perde inteiramente a confiança" (54 anos, médica). Dessa maneira, como o cliente não pode ser recuperado, é plausível afirmar que o paradoxo, neste caso, também foi inexistente.

\subsection{As três situações: uma análise geral}

Diante das situações apresentadas aos entrevistados referentes às três soluções diferentes feitas por empresas diante de uma falha de serviço, pode-se analisar que, de maneira geral, os respondentes tendem a se sentirem insatisfeitos e inconformados quando não há uma compensação pelo prejuízo causado além daquele mínimo, já esperado, levando-os a imaginar que não realizariam futuros negócios com as empresas.

É relevante ressaltar também que se percebeu um comportamento oportunista diante da falha bem resolvida da primeira situação. O consumidor oportunista é caracterizado como alguém que reconhece uma oportunidade de obter vantagens econômicas através de uma fictícia falha no serviço promovido por uma organização (BERRY; SEIDERS, 2008). Muitos entrevistados, confirmaram a existência do paradoxo de recuperação de serviço. No entanto, expressaram querer fazer negócio com a mesma empresa com a intenção de se beneficiar da vantagem dada, contando que isso se repita mais vezes para obter maiores ganhos.

Evidencia-se, portanto, a necessidade de fazer mais do que o necessário com a intenção de surpreender o cliente para, de fato, conseguir que o mesmo volte a fazer negócios mesmo depois de uma falha de serviço. Nota-se que as empresas devem dar maior importância ao setor que cuida da satisfação, o marketing, para que gere maiores receitas no longo prazo.

A Tabela 2, a seguir, mostra os principais achados da pesquisa. 
Tabela 2: Resumo da pesquisa de campo

\begin{tabular}{|c|c|c|c|}
\hline & Situação 1 & Situação 2 & Situação 3 \\
\hline $\begin{array}{l}\text { Satisfação/Insatisfação com } \\
\text { a resposta à falha de serviço }\end{array}$ & Satisfação & Insatisfação & Insatisfação \\
\hline Relatos dos Entrevistados & $\begin{array}{l}\text { "Excelente. Porque primeiro demonstrou } \\
\text { uma ótima experiência ao consumidor } \\
\text { entendendo que gerou um transtorno. } \\
\text { Segundo, Eduardo vai ficar tão feliz que } \\
\text { vai poder comprar mais coisas, até mais } \\
\text { que } 100 \text { reais." (28, advogado) }\end{array}$ & $\begin{array}{l}\text { "Em virtude desse transtorno a } \\
\text { empresa tinha que dar um agrado, } \\
\text { uma compensação, desconto na } \\
\text { próxima compra por exemplo" (28, } \\
\text { advogado) }\end{array}$ & $\begin{array}{c}\text { "Deveria se mostrar mais } \\
\text { preocupada com o que aconteceu } \\
\text { com uma abordagem mais amigável" } \\
\text { (28, advogado) }\end{array}$ \\
\hline $\begin{array}{l}\text { O que poderia melhorar na } \\
\text { recuperação do serviço }\end{array}$ & - Mudança no controle de estoque & $\begin{array}{l}\text { - Coleta do produto defeituoso na } \\
\text { casa do cliente na troca de um novo } \\
\text { imediato }\end{array}$ & $\begin{array}{c}\text { - Ter uma área responsável pelo } \\
\text { tratamento desses casos }\end{array}$ \\
\hline
\end{tabular}




\begin{tabular}{|l|c|c|c|}
\hline & & Brinde de agrado e desculpas pelo & $\begin{array}{c}\text { Demonstrar preocupação e } \\
\text { transtorno } \\
\text { interesse no problema }\end{array}$ \\
\hline $\begin{array}{c}\text { Existência do paradoxo de } \\
\text { recuperação do serviço }\end{array}$ & Ocorreu & Não ocorreu & Não ocorreu \\
\hline
\end{tabular}

Fonte: Elaboração própria (2020). 


\section{Considerações finais}

O objetivo do presente estudo foi analisar o efeito que o tipo de resolução a uma falha de serviço provoca na satisfação de consumidores, buscando, desta feita, identificar se o paradoxo de serviços se apresenta e as razões disto. Para isso, foi realizada uma pesquisa exploratória de cunho qualitativo, através de 12 entrevistas pautadas sob a técnica projetiva. A partir da análise dos dados, foram feitas considerações finais.

Com base na análise dos dados da primeira situação, a qual a empresa realizou empenhos além do mandatório para conquistar o cliente, foi possível perceber que determinadas pessoas aprovam a hipótese e outras refutam, mesmo havendo esforços por parte da empresa. Isso pelo simples fato de que as pessoas possuem sentimentos diferentes em relação a uma peça de roupa ou um produto e, assim, a gravidade da situação pode ser alta em uns casos e baixa em outros.

Portanto, tiveram pessoas que efetivamente ficaram abaladas com o erro e não voltariam a fazer negócios com a empresa enquanto tiveram outras que afirmaram que teriam a preferência por voltar a fazer negócios com a mesma em vez de comprar em organizações em que nunca havia tido falhas.

Além disso, por meio das outras duas situações, foi possível perceber que rotineiramente as empresas perdem os clientes por não demonstrar o valor que ele possui para a mesma. Dessa forma, quando a empresa opta por realizar apenas o que é obrigatório, transmite uma imagem péssima ao cliente e se torna prejudicial para ela. Assim sendo, para que seja feita uma recuperação de serviço eficaz, deve-se cativar o consumidor lesado através de bônus, brindes, descontos e atitudes que demonstrem significância do cliente. O agrado acaba sendo um fator determinantes para futuros negócios.

Portanto, após a análise feita, foi viável identificar a relevância da interação dos elementos sociais, psicológicos, ambientais, políticos e tecnológicos, simultaneamente, diante a decisão de consumo. Com isso, foi possível constatar a existência do paradoxo somente na situação 1, na qual os entrevistados disseram estar mais propensos a fazer novos negócios com a empresa que já passaram por uma falha bem resolvida em vez de qualquer outra 
com quem não tiveram uma falha. Isso porque, nas outras duas situações, não houve recuperação, não podendo existir o paradoxo por consequência.

\subsection{Implicações gerenciais}

Com base nas análises e conclusões precedentes e no reconhecimento da importância da recuperação de clientes, é necessário que as empresas estejam cientes de que o tratamento do cliente no pós-venda é tão relevante quanto antes de realizar a venda em si. Atitudes insatisfatórias podem ser prejudiciais à sua própria imagem e, consequentemente, a suas vendas.

A satisfação dos consumidores anteriores é um fatores determinantes da tomada de decisão dos novos consumidores, principalmente no e-commerce. Além disso, com a existência de diversos sites de reclamação com fácil acesso para os clientes, é ainda mais necessário que o consumidor saia contente.

Para empresas, é recomendável, então, que provoquem meios que façam o paradoxo de recuperação de clientes existir, pois o mesmo comprova que está solucionando falhas de maneira assertiva provocando a fidelização da clientela, o que é favorável para ela.

Portanto, assim que identificar uma falha no serviço: 1) a empresa deve assumir o erro; 2) se mostrar disposta a solucionar a vida do cliente; e 3) além de solucionar o problema em si, agradá-lo. Existem diversas formas de deixar o cliente com uma imagem positiva da empresa: brindes que tenham a ver com o produto (se for um liquidificador, uma colher por exemplo), descontos nas próximas compras ou um vale para usufruir na loja. É indispensável que o consumidor se sinta devidamente recompensado pelo contratempo e a recompensa deve ser boa ao ponto que o consumidor nem se importe mais com ela.

Ademais, a empresa deve dar atenção especial no desenho dos processos do pós-venda, de modo que não passe para o cliente responsabilidades que deveriam ser dos mesmos diante de uma falha no serviço. No caso das situações 2 e 3, foi possível notar um processo falho que deixou o cliente frustrado. Nesses casos, quanto menor for o envolvimento do cliente na resolução do problema, melhor, pois o mesmo não quer ser incomodado visto que não tem culpa do ocorrido. 


\subsection{Sugestões e recomendações para futuros estudos}

Para pesquisas futuras, recomenda-se a escolha de um público-alvo mais diversificado, a fim de se obter resultados mais relevantes para o objeto de pesquisa. $O$ fato de a maioria dos entrevistados serem estudantes com idades entre 19-25 anos pode influenciar a análise porque, segundo o relatório Webshoppers, da Ebit, a idade média dos consumidores de loja online é 42,2 anos.

Com o objetivo de aprimorar o presente estudo, indica-se realizar uma pesquisa quantitativa, explorando um maior número de respondentes para avaliar qual a frequência que ocorre uma recuperação, se há paradoxo em larga escala ou em qual setor que as pessoas mais passaram por essa situação.

Além disso, sugere-se realizar pesquisas sobre as situações reais que as pessoas possam ter vivenciado, com foco em áreas como saúde ou telecomunicações, para entender o desempenho da empresa em relação aos clientes na perspectiva dos consumidores. 


\section{Referências Bibliográficas}

BERRY, L.; SEIDERS, K. Serving unfair customers. Business Horizon 51, 2008.

BODDY, C. R. (2007). Projective techniques in Taiwan and Asia-Pacific market research. Qualitative Market Research: An International Journal, 10 (1), 48-62.

BOND, D.; RAMSEY, E. (2010). The role of information and communication technologies in using projective techniques as survey tools to meet the challenges of bounded rationality. Qualitative Market Research: An,13 (4), 430440.

CASOTTI, L.; HEMAIS, M. Passivos, Reativos e Sentimentais - Consumidores de Baixa Renda Projetam suas Insatisfações. EnANPAD, 2010.

CHURCHILL, G. A., \& IACOBUCCI. (2002). Marketing research: methodological foundations (8th ed.). United States: Thomson Learning.

Ebit | Nielsen. Reputação de lojas virtuais e dados para o mercado online. Disponível em: <https://company.ebit.com.br/webshoppers>. Acesso em: 20 de novembro de 2020.

FORNELL, C. A National Customer Satisfaction Barometer: The Swedish Experience. Journal of Marketing, v. 56, p. 6-21, January, 1992.

GRÖNROOS, C. Marketing, gerenciamento e serviços: a competição por serviços na hora da verdade. Rio de Janeiro: Campus, 1995.

HOFFMAN, K. D.; BATESON, J. E. G. Princípios de Marketing de Serviços Conceitos, Estratégias e Casos. São Paulo: Pioneira Thomson Learning, 2003.

KOTLER, P. Administração de Marketing - A edição do Novo Milênio. 10 Edição. São Paulo: Prentice Hall, 2000.

KOTLER, P.; KELLER, K. L. Administração de marketing. 12 ed. São Paulo: Pearson, 2006.

LOVELOCK, Christopher; WIRTZ, Jochen. Marketing de Serviços: Pessoas, Tecnologia e Resultados. São Paulo: Pearson Prentice Hall, 2006.

MALHOTA, N. Pesquisa de marketing: uma orientação aplicada / Nares Malhotra; trad. Nivaldo Montingelli Jr. e Alfredo Alves de Farias. - 3. ed. - Porto Alegre: Bookman, 2001.

OLIVER, R. L. Satisfaction: a behavioral perspective on the consumer. New York, NY: McGraw Hill, 1997

OLIVER, R. L. Whence consumer loyalty? Journal of Marketing, Special Issue, $p$. 33-44, 1999. 
TINOCO, M. e RIBEIRO, J. (2007), "Uma nova abordagem para a modelagem das relações entre os determinantes da satisfação dos clientes de serviços", Revista Produção, V. 17, N. 3.

WILL, V.; EADIE, D.; MacASKILL, S. Projective and enabling techniques explored. Marketing Intelligence \& Planning, v. 14, n. 6, 1996.

ZIKMUND, William G.. Princípios da Pesquisa de Marketing: Uma orientação aplicada. São Paulo, tradução da 2ª edição norte-americana, 2006. 


\section{Apêndice 1 - Formulário de entrevistas}

\section{Situações da Técnica Projetiva}

1. Julia/Eduardo decidiu fazer compras em um site de roupas na internet. Escolheu 6 peças e fez o pagamento. Um dia depois ela/ele recebeu um e-mail informando que uma peça que escolheu não tinha mais no estoque. A empresa, para solucionar o problema mencionado, estornou o valor da peça no cartão e ainda disponibilizou 100 reais para Julia/Eduardo gastar com o que quisesse na loja, inclusive com frete grátis.

- O que você acha da solução oferecida pela empresa a Julia/Eduardo?

- Você acha que a empresa poderia ter feito algo diferente, nessa situação?

- Você acha que Julia/Eduardo ficou feliz com a solução oferecida pela empresa?

- Julia/Eduardo deveriam voltaria a fazer negócios com ela após essa solução?

- Após passado essa solução, Julia/Eduardo se vê em uma situação em que quer comprar um produto e está disponível em duas lojas, essa e uma outra em que ele nunca teve problema, qual loja seria mais provável fechar negócio?

2. João Felipe/Juliana realizou uma compra de um multiprocessador de cozinha pela internet. Dias depois, o produto chegou em sua residência, mas estava quebrado. João Felipe/Juliana entrou em contato com a empresa, que, por sua vez, pediu a ele/ela que retornasse o produto pelos correios, para que o valor da compra pudesse ser estornado no seu cartão de crédito em até duas faturas.

- O que você acha da solução oferecida pela empresa a João Felipe/Juliana?

- Você acha que a empresa poderia ter feito algo diferente, nessa situação? 
- Você acha que João Felipe/Juliana ficou feliz com a solução da empresa?

- João Felipe/Juliana deveriam voltaria a fazer negócios com ela após essa solução?

3. Marcelo/Claudia realizou a compra de um liquidificador na internet. A empresa deu a ele/ela um prazo de entrega longo, mas, mesmo assim, o pedido não chegou no tempo estipulado. Marcelo/Claudia tentou contato com a empresa e a mesma retornou que, por ser uma compra realizada em um marketplace, ele/ela deveria entrar em contato com a loja que vez a venda, pois a empresa não tinha culpa pelo problema.

- O que você acha da solução oferecida pela empresa a Marcelo/Claudia?

- Você acha que a empresa poderia ter feito algo diferente, nessa situação?

- Você acha que Marcelo/Claudia ficou feliz com a solução da empresa?

- Marcelo/Claudia deveriam voltaria a fazer negócios com ela após essa solução? 



\section{Apêndice 2 - Respostas dos entrevistados}

\begin{tabular}{|c|c|c|c|c|c|c|c|}
\hline & & & \multicolumn{5}{|c|}{ Situação 1} \\
\hline $\mathrm{N}^{\circ}$ & - Idade & Profissão & 1 & 2 & 3 & 4 & 4 Extra \\
\hline M 1 & 54 & Médica & $\begin{array}{l}\text { Excelente. Porque a empresa poderia } \\
\text { falar apenas que não tinha mais, no } \\
\text { entanto para compensar a frustação, a } \\
\text { empresa ainda deu presente para cliente. }\end{array}$ & $\begin{array}{l}\text { Melhor do que isso, não. Ela poderia } \\
\text { simplesmente pedir desculpas e estornar } \\
\text { o valor. A empresa realmente tentou se } \\
\text { redimir da falha. }\end{array}$ & $\begin{array}{l}\text { Acho que sim porque surpreendeu } \\
\text { positivamente, talvez a cliente nem } \\
\text { esperasse por isso. }\end{array}$ & $\begin{array}{l}\text { Com certeza. Apesar da situação de não } \\
\text { ter as peças no estoque, foi uma atitude } \\
\text { louvável. }\end{array}$ & $\begin{array}{l}\text { Depende muito. Se isso for pontual e } \\
\text { jamais aconteceu na empresa, ela } \\
\text { escolheria a que gostou mais e a que } \\
\text { conviesse. Eu não deixaria de comprar na } \\
\text { loja pelo fato ocorrido. Não é uma } \\
\text { situação de escolher ou não a loja. }\end{array}$ \\
\hline M 2 & 61 & Aposentada & Solução perfeita. & $\begin{array}{l}\text { Deveria ter um controle de estoque para } \\
\text { que isso não acontecesse. }\end{array}$ & $\begin{array}{l}\text { Sim, pois ela vai comprar mais roupa. Ela } \\
\text { não saiu no prejuízo e pode procurar o } \\
\text { que quiser em outro lugar com o valor } \\
\text { estornado. }\end{array}$ & $\begin{array}{l}\text { Acho que sim, me colocando no lugar } \\
\text { dela. Não sou uma pessoa muito } \\
\text { exigente. }\end{array}$ & $\begin{array}{l}\text { Faria com a outra que não teve problema } \\
\text { nenhum. Pois tem } 50 \% \text { de chances de } \\
\text { dar certo. }\end{array}$ \\
\hline M 3 & 52 & Psicóloga & $\begin{array}{l}\text { Achou boa a solução e ia comprar } \\
\text { novamente. Acha que é um estimulo para } \\
\text { fidelizar o cliente. }\end{array}$ & $\begin{array}{l}\text { Seria a melhor solução que a empresa } \\
\text { poderia ter feito. }\end{array}$ & $\begin{array}{l}\text { Acha que sim. Porque ela não ficou no } \\
\text { prejuízo. Vai poder recuperar o que ela } \\
\text { tinha investido. Estornaram a compra e } \\
\text { ela ganhou bônus }\end{array}$ & $\begin{array}{l}\text { Sim. Acha que deveria fazer negócios } \\
\text { com essa empresa. }\end{array}$ & $\begin{array}{l}\text { Compraria nessa mesma loja. porque ela } \\
\text { teve uma boa solução e uma } \\
\text { recompensa. A recompensa estimula } \\
\text { você manter o padrão de compra, manter } \\
\text { a satisfação da compra. Não arriscaria } \\
\text { em um outro lugar que nao saberia a } \\
\text { resposta. }\end{array}$ \\
\hline M 4 & 27 & $\begin{array}{l}\text { Servidora } \\
\text { pública }\end{array}$ & $\begin{array}{l}\text { Como consumidora, achei ótima a } \\
\text { solução, mas talvez para a empresa seja } \\
\text { oneroso demais para arcar com esses } \\
\text { custos a cada erro. }\end{array}$ & $\begin{array}{l}\text { Não, eu já ficaria satisfeita se eles } \\
\text { estornassem o dinheiro sem problemas. } \\
\text { Com frete grátis e mais } 100 \text { reais eu } \\
\text { achei perfeito. Prefiro essa solução do } \\
\text { que eventualmente trocar minha roupa. }\end{array}$ & $\begin{array}{l}\text { Sim. Porque diante do problema a } \\
\text { empresa não só devolveu o dinheiro como } \\
\text { ainda conferiu um agrado a mais com o } \\
\text { vale e frete grátis. Diante do problema - } \\
\text { que é insolucionvel visto que a empresa } \\
\text { não tem como virar o produto - seria a } \\
\text { melhor solução. }\end{array}$ & Sim. & $\begin{array}{l}\text { Teria mais chance com essa empresa } \\
\text { que ela ja teve um problema bem } \\
\text { solucionado. A Julia voltaria a fazer } \\
\text { negócios porque foi muito bem atendida } \\
\text { no pós venda que é indispensável no e- } \\
\text { commerce, já que é um serviço que o } \\
\text { contato com o cliente é mais difícil. }\end{array}$ \\
\hline M 5 & 22 & Estudante & $\begin{array}{l}\text { Achei ótimo. A solução foi boa porque fui } \\
\text { estornada e ganhei dinheiro. }\end{array}$ & $\begin{array}{l}\text { Se era uma coisa que ela queria } \\
\text { urgentemente, pode ter dado uma maior } \\
\text { dor de cabeça para ela. Talvez uma } \\
\text { resposta mais rápida, mas dependendo } \\
\text { da hora nao tem muito como resolver só } \\
\text { se fosse uma resposta automática. Eu } \\
\text { acho que eu teria saido bem feliz com } \\
100 \text { reais + estorno + frete gratis. E-mail } \\
\text { com perspectiva de melhora no controle } \\
\text { do estoque (pedir desculpas pelo erro). }\end{array}$ & $\begin{array}{l}\text { Sim, porque vai ter mais dinheiro pra } \\
\text { comprar mais roupa. }\end{array}$ & $\begin{array}{l}\text { A solução foi boa, me agradaria bastante } \\
\text { e nao fiquei irritada por causa da solução } \\
\text { porque foi bem resolvido. Fizeram bem e } \\
\text { cativou, mas tem que ter perspectiva de } \\
\text { melhora. Mas se tiver, sim. Se } \\
\text { acontecesse de novo ficaria muito } \\
\text { irritada. }\end{array}$ & $\begin{array}{l}\text { Se eu tivesse uma identificação com a } \\
\text { loja, voltaria a fazer com que deu } \\
\text { problema. }\end{array}$ \\
\hline M 6 & 21 & Estudante & $\begin{array}{l}\text { Amei. Já ficaria bem se eles me } \\
\text { estornassem o dinheiro e fiquei muito } \\
\text { surpresa com a solução de dar mais } 100 \\
\text { reais. }\end{array}$ & $\begin{array}{l}\text { Atualizar mais rápido o site para não } \\
\text { ocorrer isso de novo, porque eles estao } \\
\text { perdendo dinheiro nisso tudo. O processo } \\
\text { de estoque tem que ser mais rápido. A } \\
\text { solução foi muito boa, já ficaria satisfeita } \\
\text { só com o estorno da peça, isso foi } \\
\text { maravilhoso. }\end{array}$ & A Júlia, eu não sei, mas a Jéssica ficaria. & $\begin{array}{l}\text { Sim, com certeza. Achei que foi uma } \\
\text { ótima solução. Se fosse só o estorno, } \\
\text { acho que não. }\end{array}$ & $\begin{array}{l}\text { Se fosse eu, compraria na mesma loja } \\
\text { com certeza. Já tem a garantia que se } \\
\text { tiver problema vai ficar tudo bem. }\end{array}$ \\
\hline H 7 & 25 & Estudante & $\begin{array}{l}\text { Achei legal como uma medida para } \\
\text { compensar ele de uma maneira justa } \\
\text { sem prejudicar a empresa, gostei. }\end{array}$ & $\begin{array}{l}\text { Teria que ter um melhor controle de } \\
\text { estoque mas como medida paleativa não. }\end{array}$ & $\begin{array}{l}\text { Não sei se feliz seria a palavra certa, mas } \\
\text { ele teve um retorno muito positivo da } \\
\text { empresa. }\end{array}$ & $\begin{array}{l}\text { Sim, até porque eles deram uma solução } \\
\text { justa. }\end{array}$ & $\begin{array}{l}\text { Com a que nunca deu problema, porque } \\
\text { por mais que a empresa tenha } \\
\text { solucionado depois, é melhor fazer com } \\
\text { uma empresa que nunca deu problema. }\end{array}$ \\
\hline H 8 & 25 & Estudante & $\begin{array}{l}\text { Uma solução muito boa, pois ele teve } \\
\text { prejuizo de perder a peça que ele queria. } \\
\text { Mas a empresa fez certo, porque } \\
\text { estornou o valor e ainda deu um bônus } \\
\text { pelo que fez ele passar. }\end{array}$ & $\begin{array}{l}\text { Eu ficaria muito satisfeito com a situação } \\
\text { colocado. Acho que foi a melhor solução, } \\
\text { não pensaria em nada diferente. }\end{array}$ & $\begin{array}{l}\text { Sim, acho que ele ficou feliz porque ele } \\
\text { teve o seu prejuizo estornado e ainda } \\
\text { recebeu um presente para gastar com o } \\
\text { que quisesse na loja. }\end{array}$ & $\begin{array}{l}\text { Deveria, porque a empresa soube } \\
\text { reconhecer seu erro e disponibilizou } \\
\text { bonus para compensar o transtorno } \\
\text { causado. Atitude da empresa faz pensar } \\
\text { que se preocupa de verdade com o } \\
\text { cliente. }\end{array}$ & $\begin{array}{l}\text { Tem algumas variáveis. Se ele precisasse } \\
\text { muito da peça, talvez comprasse na loja } \\
\text { que nao tenha dado problema no } \\
\text { estoque. Mas se fosse numa situação } \\
\text { hipotética, compraria na loja que teve } \\
\text { uma falha bem resolvida, porque ele já } \\
\text { tem uma garantia de que se preocupam. }\end{array}$ \\
\hline H 9 & 28 & Advogado & $\begin{array}{l}\text { Excelente. Porque primeiro demonstrou } \\
\text { uma ótima experiência ao consumidor } \\
\text { entendendo que gerou um transtorno. } \\
\text { Segundo, Eduardo vai ficar tao feliz que } \\
\text { vai poder comprar mais coisas, até mais } \\
\text { que } 100 \text { reais. }\end{array}$ & Não, foi ótimo. & $\begin{array}{l}\text { Com certeza, porque ele se sentiu } \\
\text { valorizado e visto como um consumidor. } \\
\text { Se sentiu respeitado como uma pessoa e } \\
\text { não como um número de pedido. }\end{array}$ & $\begin{array}{l}\text { Sim, com certeza! Ainda deveria torcer } \\
\text { para que os pedidos não tivessem no } \\
\text { estoque. }\end{array}$ & $\begin{array}{l}\text { É obvio que ele vai comprar na mesma } \\
\text { empresa. A empresa ganhou } \\
\text { credibilidade e confiança do Eduardo. No } \\
\text { futuro, mesmo que tenha tido problema, } \\
\text { ele deve voltar a fazer negócios com a } \\
\text { empresa que o valorizou. }\end{array}$ \\
\hline H 10 & 22 & Estudante & $\begin{array}{l}\text { Acho excelente. Acho que a partir do } \\
\text { momento que eles reconheceram o erro e } \\
\text { chegaram numa solução é muito bom. } \\
\text { Para mim, quando eu compro roupa eu } \\
\text { quero muito um produto, as vezes o } \\
\text { estorno nao soluciona a minha vida e } \\
\text { visão na empresa. A ideia de dar } 100 \\
\text { reais é muito boa, porque quando } \\
\text { ganhamos o bonus dar um ar de } \\
\text { preocupação e reconhecimento do erro. }\end{array}$ & $\begin{array}{l}\text { Sim, tentar arrumar a peça de qualquer } \\
\text { jeito, ver com o fabricante, estoque em } \\
\text { outras lojas e fazer de tudo internamente } \\
\text { para conseguir o produto. Mostrar que } \\
\text { estar se preocupando com o desejo da } \\
\text { pessoa por aquele produto. }\end{array}$ & $\begin{array}{l}\text { Acho que deve ter ficado feliz no final } \\
\text { porque o ser humano ama sair na } \\
\text { vantagem. Mas mesmo assim vai ainda } \\
\text { ficar um pouco decepcionado por não ter } \\
\text { a peça que ele queria. No final, a } \\
\text { felicidade > decepção. }\end{array}$ & $\begin{array}{l}\text { Acho sim. Eu sou uma pessoa muito fiel } \\
\text { as marcas que eu compro. Quando eu } \\
\text { compro e gosto, vou comprar sempre } \\
\text { com essa marca. Deve voltar porque sabe } \\
\text { que sempre vai ter preocupaçãa por parte } \\
\text { da empresa. }\end{array}$ & $\begin{array}{l}\text { Eu acho que tenderia a fazer negocio } \\
\text { com que ele já consumiu. Ele já sabe } \\
\text { que as pessoas da empresa ele já sabe } \\
\text { e como será se houver um problema. Ele } \\
\text { tem uma garantia com esse problema e } \\
\text { não tem na outra loja. }\end{array}$ \\
\hline H 11 & 23 & Professor & $\begin{array}{l}\text { Muito boa, porque como ele saiu lesado } \\
\text { na história a empresa ofereceu um } \\
\text { bônus. Então ele perdeu a peça mas teve } \\
\text { uma compensação. }\end{array}$ & $\begin{array}{l}\text { Acho que só se tentar ver se tem em } \\
\text { outro lugar, procurar solucionar com } \\
\text { outras peças similares ou se vão produzir } \\
\text { mais. }\end{array}$ & $\begin{array}{l}\text { Sim, porque ele ganhou um presente para } \\
\text { usar. }\end{array}$ & Sim, com certeza. Eu faria. & Na que ele nunca teve problema. \\
\hline H 12 & 24 & Administrador & É ótimo! Está perfeito o que eles fizeram. & $\begin{array}{l}\text { Não, acho que a empresa fez mais do } \\
\text { que precisava. }\end{array}$ & $\begin{array}{l}\text { Sim, com certeza! Ele ganhou um } \\
\text { presente e a empresa entendeu que errou } \\
\text { e foi proativa na solução }\end{array}$ & Sim! Não vejo porque não. & $\begin{array}{l}\text { Na que ele nunca teve problema, porque } \\
\text { eu sou um cara que por mais que a } \\
\text { empresa tenha dado garantias, prefiro a } \\
\text { que não teve problema. }\end{array}$ \\
\hline
\end{tabular}




\begin{tabular}{|c|c|c|c|c|c|c|}
\hline \multirow[b]{2}{*}{$\mathrm{N}^{\circ}$} & \multirow[b]{2}{*}{ Idade } & \multirow[b]{2}{*}{ Profissão } & \multicolumn{4}{|c|}{ Situação 2} \\
\hline & & & 1 & 1 & 3 & 4 \\
\hline M 1 & 54 & Médica & $\begin{array}{l}\text { Péssima. Se o produto veio quebrado a empresa } \\
\text { tinha que ter vindo retirar o produto na casa. } \\
\text { Porque foi uma falha na empresa e a solução } \\
\text { tinha que ser imediata pro cliente. }\end{array}$ & $\begin{array}{l}\text { Sim. Pedido fotos, na mesma hora se prontificar } \\
\text { a substituir o produto, pedindo desculpas, dar } \\
\text { bônus de frete grátis. É uma frustação a Juliana } \\
\text { e uma falta de cuidado da empresa. }\end{array}$ & $\begin{array}{l}\text { Não. Porque ela vai ter que esperar mais pelo } \\
\text { produto, vai ter que perder tempo indo aos } \\
\text { correios e ainda vai demorar para ter o dinheiro } \\
\text { para comprar de novo. }\end{array}$ & Não. \\
\hline M 2 & 61 & Aposentada & $\begin{array}{l}\text { Solução que todo mundo faz. Não gosta de ter a } \\
\text { responsabilidade de ter que colocar o produto } \\
\text { quebrado nos correios. }\end{array}$ & $\begin{array}{l}\text { Sim. Poderia ter recolhido na casa da cliente } \\
\text { assumindo o erro e o problema, sem causar } \\
\text { transtornos ao dia a dia da cliente. }\end{array}$ & $\begin{array}{l}\text { Não, porque a empresa tinha que ter se } \\
\text { responsabilizado e ela terá que ter tempo de } \\
\text { levar no correio. }\end{array}$ & Não, de jeito nenhum. \\
\hline M 3 & 52 & Psicóloga & $\begin{array}{l}\text { Detestei, porque eu não iria nos correios devolver } \\
\text { o produto de jeito nenhum. Eu ia reclamar muito. }\end{array}$ & $\begin{array}{l}\text { A cliente poderia ter mandado uma foto do } \\
\text { produto mostrando que o produto estava com } \\
\text { defeito e a loja tem que acreditar no consumidor. }\end{array}$ & Não. Ela deve ter achado um porre. & $\begin{array}{l}\text { Não. Porque é trabalhoso. Se a pessoa compra } \\
\text { pela internet ela quer comodidade, rapidez. Se } \\
\text { vai ter que ir nos correios fazer alguma coisa é } \\
\text { melhor ir na loja. }\end{array}$ \\
\hline M 4 & 27 & Servidora pública & $\begin{array}{l}\text { Acho a solução ruim, se eu fosse a juliana eu } \\
\text { nao iria querer ir ao correio perdendo o tempo. } \\
\text { Se o produto veio com defeito, a empresa que } \\
\text { tem que buscar o produto com defeito. O } \\
\text { movimento de ter que ir ao correio e o reembolso } \\
\text { estar condicionado a isso é um absurdo para o } \\
\text { cliente. }\end{array}$ & $\begin{array}{l}\text { Sim. Poderia ter se disponibilizado para buscar o } \\
\text { produto defeituoso e efetuar o estorno do valor ou } \\
\text { ainda fazer a troca levando o produto novo a } \\
\text { casa da cliente e buscando o antigo. }\end{array}$ & Não. & Não. \\
\hline M 5 & 22 & Estudante & $\begin{array}{l}\text { Péssima. Porque não quero devolver o produto } \\
\text { se ele veio quebrado, parece que a gente ta } \\
\text { mentindo. }\end{array}$ & $\begin{array}{l}\text { Acho que sim. Pedido para cliente enviar foto e } \\
\text { identificar qual foi o erro, se foi na parte eletrica, } \\
\text { ou se o pote veio quebrado (identificar em qual } \\
\text { momento foi o erro na linha de produção). Tinha } \\
\text { que ter dado algo além. }\end{array}$ & Não, insatisfeita, decepcionada. & $\begin{array}{l}\text { Não voltará a comprar, tenderia a fazer com } \\
\text { outras. }\end{array}$ \\
\hline M 6 & 21 & Estudante & $\begin{array}{l}\text { Uma merda. Achei ruim a parte de ir aos } \\
\text { correios. }\end{array}$ & $\begin{array}{l}\text { Ela poderia ter enviado o mesmo produto em } \\
\text { perfeitas condições junto a um brinde com o } \\
\text { mesmo tema de cozinha (alguma colher, algo } \\
\text { assim). }\end{array}$ & $\begin{array}{l}\text { Não, porque eu não gostaria de receber um } \\
\text { produto quebrado e receber o dinheiro depois de } \\
\text { duas faturas. O dinheiro tinha que ser imediato e } \\
\text { o produto também. }\end{array}$ & Não, eu não compraria mais nada nessa loja. \\
\hline H 7 & 25 & Estudante & $\begin{array}{l}\text { Não acho boa, porque você ainda está fazendo } \\
\text { ele ter um desgaste de ter que levar aos correios } \\
\text { e já teve o desgaste de estar quebrado. }\end{array}$ & $\begin{array}{l}\text { Podia ter reenviado outro produto funcionando e } \\
\text { coletar o produto que estava com defeito mas } \\
\text { nao pedir para o cliente fazer isso. }\end{array}$ & Não. Acho que ele ficou bem puto & Não, de jeito nenhum. \\
\hline H 8 & 25 & Estudante & $\begin{array}{l}\text { Uma solução ruim, pois o cliente só teve um } \\
\text { ônus. Além não conseguir o produto que ele } \\
\text { queria, ainda vai ter que se deslocar ao correios } \\
\text { e perder tempo, sem contar que o valor nao será } \\
\text { creditado imediatamente. }\end{array}$ & $\begin{array}{l}\text { Sim, podia buscar o produto e fazer algum } \\
\text { agrado ao cliente. }\end{array}$ & $\begin{array}{l}\text { Foi melhor do que a empresa falar sinto muito, } \\
\text { mas não ficou feliz. }\end{array}$ & $\begin{array}{l}\text { Não, não voltaria a fazer negócio com essa } \\
\text { empresa. }\end{array}$ \\
\hline $\mathrm{H} 9$ & 28 & Advogado & $\begin{array}{l}\text { Considerando que eu tenho oportunidades de } \\
\text { melhoria, eu achei ruim. }\end{array}$ & $\begin{array}{l}\text { Em virtude desse transtorno a empresa tinha que } \\
\text { dar um agrado, uma compensação, desconto na } \\
\text { proxima compra por exemplo. Segundo, a } \\
\text { empresa poderia dar a condição de uma entrega } \\
\text { mais rápida caso eu queira o mesmo produto. } \\
\text { Acho que faltou um pouco de cuidado com o } \\
\text { consumidor. Para que o João olhasse para } \\
\text { empresa e pudesse ver que a empresa está } \\
\text { preocupada com ele }\end{array}$ & $\begin{array}{l}\text { Não, porque foi uma solução totalmente } \\
\text { operacional e distanciada do consumidor e acho } \\
\text { que a gente não sabe qual a urgencia que ele } \\
\text { precisava do produto, mas caso ele precisasse } \\
\text { ela tinha que entregar da forma rápida o produto } \\
\text { que ele solicitou. }\end{array}$ & Não, a não ser que seja muito necessário. \\
\hline H 10 & 22 & Estudante & $\begin{array}{l}\text { Fico muito indignado com a questão e ter um } \\
\text { problema e eu tenho que perder meu tempo } \\
\text { saindo de casa e indo fazer as coisas que é erro } \\
\text { dos outros. }\end{array}$ & $\begin{array}{l}\text { Buscar a peça na casa da pessoa e estornar o } \\
\text { valor imediatamente, pois vira uma preocupação } \\
\text { se aquele dinheiro realmente vai ser estornado } \\
\text { ou não e ele fica muito tempo sem o dinheiro e o } \\
\text { produto. }\end{array}$ & $\begin{array}{l}\text { Não mesmo, primeiro que não tiveram cuidado } \\
\text { com o produto para ele chegar em perfeitas } \\
\text { condições. Ele teve muita dor de cabeça nesse } \\
\text { pós venda. }\end{array}$ & $\begin{array}{l}\text { Não mesmo, eu fico muito indignado quando me } \\
\text { tratam assim. }\end{array}$ \\
\hline H 11 & 123 & Professor & $\begin{array}{l}\text { Acho ruim, porque você não tem o produto. Vai } \\
\text { acabar tendo } 2 \text { trabalhos (ir ao correios e depois } \\
\text { esperar a devolução do dinheiro). }\end{array}$ & $\begin{array}{l}\text { Sim, poderiam trocar o produto ou se pudesse } \\
\text { ter uma assistência técnica ir a casa dele pra } \\
\text { trocar o produto ou a peça que tivesse quebrada. }\end{array}$ & Não, ficou bem bolado. & $\begin{array}{l}\text { Depende, só se ele precisar muito (ser essencial } \\
\text { ou não) e se ele pesquisar e ver que não é algo } \\
\text { que acontece muito. }\end{array}$ \\
\hline H 12 & 24 & Administrador & $\begin{array}{l}\text { Solução é média, porque resolve o problema. A } \\
\text { parte de mandar pro correio é praxe. Mas pro } \\
\text { cara não foi bom, porque ele deve precisar o } \\
\text { dinheiro e do produto. }\end{array}$ & Poderia ter estornado o valor na mesma hora. & Acho que não, eu não me sentiria feliz com isso. & $\begin{array}{l}\text { Acho que não inviabiliza futuros negócios, faz } \\
\text { parte. Pode voltar a fazer futuros negócios, mas } \\
\text { se acontecer de novo, nunca mais. }\end{array}$ \\
\hline
\end{tabular}




\begin{tabular}{|c|c|c|c|c|c|c|c|}
\hline \multirow{2}{*}{\multicolumn{2}{|c|}{$\mathrm{N}^{\circ}$}} & \multirow[b]{2}{*}{ Idade } & \multirow[b]{2}{*}{ Profissão } & \multicolumn{4}{|c|}{ Situação 3} \\
\hline & & & & 1 & 2 & 3 & 4 \\
\hline M & 1 & 54 & Médica & Lamentável. Absurda. Péssima. & $\begin{array}{l}\text { Sim. A empresa deveria pedir } \\
\text { desculpas, entrar em contato com o } \\
\text { fornecedor e verificar o ocorrido. Caso } \\
\text { ainda demorasse mais, a empresa } \\
\text { deveria cancelar o pedido da cliente e } \\
\text { estornar o valor o mais rápido possível. } \\
\text { O cliente não tem nada a ver com as } \\
\text { normas da parceria. Responsabilidade é } \\
\text { da marca que está colocando seu nome } \\
\text { na frente para vender o produto. }\end{array}$ & $\begin{array}{l}\text { Claro que não. Porque quem tem que } \\
\text { resolver é a empresa que escolheu para } \\
\text { fazer a compra. A empresa que tem que } \\
\text { responsabilizar pelos trâmites e não o } \\
\text { consumidor. }\end{array}$ & $\begin{array}{l}\text { Não. Porque perde inteiramente a } \\
\text { confiança. }\end{array}$ \\
\hline M & 2 & 61 & Aposentad & $\begin{array}{l}\text { Está errado porque mesmo sendo um } \\
\text { marketplace quem assume a entrega é } \\
\text { da marca. }\end{array}$ & $\begin{array}{l}\text { Sim, assumido o erro e ter entrado em } \\
\text { contato com o fornecedor para saber o } \\
\text { que aconteceu. }\end{array}$ & Não. & Não. \\
\hline M & 3 & 52 & Psicóloga & $\begin{array}{l}\text { Acha ruim, pois a responsabilidade é do } \\
\text { site pelo qual você compra. O cliente } \\
\text { não tem que ficar correndo atrás de } \\
\text { fornecedor. }\end{array}$ & $\begin{array}{l}\text { Sim. Poderia ter assumido a } \\
\text { responsabilidade do problema. Investigar } \\
\text { e dar uma solução. }\end{array}$ & Não ficou feliz. & $\begin{array}{l}\text { Eu acho que não, porque ela comprou a } \\
\text { mercadoria e a empresa tinha que ter } \\
\text { uma solução. É melhor arriscar em } \\
\text { outra. }\end{array}$ \\
\hline M & 4 & 27 & $\begin{array}{l}\text { Servidora } \\
\text { pública }\end{array}$ & $\begin{array}{l}\text { Ruim, péssima. A partir do momento } \\
\text { que a Claudia comprou o produto na } \\
\text { plataforma digital da empresa, mesmo } \\
\text { que seja um marketplace ambas são } \\
\text { responsáveis pela venda. Não pode } \\
\text { transferir a responsabilidade para outra } \\
\text { empresa. }\end{array}$ & $\begin{array}{l}\text { A empresa deveria solucionar o } \\
\text { problema se desculpando e entrando } \\
\text { em contato com a empresa para que o } \\
\text { liquidificador chegue o mais rápido } \\
\text { possível e verificando o corrido. Uma } \\
\text { outra solução seria dar um vale ou ter } \\
\text { estornado o valor da compra } \\
\text { imediatamente. }\end{array}$ & Não. Acho que ela ficou bem irritada. & Não. \\
\hline M & 5 & 22 & Estudante & $\begin{array}{l}\text { Péssima. Achei uma resposta ok. Mas } \\
\text { mesmo sendo marketplace eles tinham } \\
\text { que ter uma área fazer esse intermédio. } \\
\text { Imagina sempre que for fazer uma } \\
\text { compra na americanas tem que ter } \\
\text { contato com essas mini empresas... }\end{array}$ & $\begin{array}{l}\text { Sim, ter feito intermédio entre o cliente } \\
\text { e a empresa, ter uma área reponsável } \\
\text { por isso. }\end{array}$ & $\begin{array}{l}\text { Não, ficou irritada, insatisfeita, porque } \\
\text { ela queria que a empresa resolvesse o } \\
\text { problema. A empresa passou a bola pro } \\
\text { outro só. }\end{array}$ & $\begin{array}{l}\text { Depende da dependência da cliente } \\
\text { com a empresa. Se tiverem outras com } \\
\text { o mesmo produto, não. A empresa } \\
\text { parece nao ter nenhuma perspectiva de } \\
\text { mudança. }\end{array}$ \\
\hline M & 6 & 21 & Estudante & $\begin{array}{l}\text { Horrorosa, não deu nenhuma } \\
\text { assistência ao cliente. }\end{array}$ & $\begin{array}{l}\text { Sim, reportar ao vendedor. Entrar em } \\
\text { contato com ele e fazer o intermédio } \\
\text { dessa situação. Porque é o nome da } \\
\text { empresa que está em jogo. }\end{array}$ & $\begin{array}{l}\text { Não, zero. Ela não teve nenhuma } \\
\text { assistência e parece que a empresa } \\
\text { não se importou com o que estava } \\
\text { acontecendo. }\end{array}$ & $\begin{array}{l}\text { Não, de jeito nenhum porque não teve } \\
\text { solução }\end{array}$ \\
\hline $\mathrm{H}$ & 7 & 25 & Estudante & $\begin{array}{l}\text { Achei uma resposta justa, pois eles não } \\
\text { tinham como saber onde tava o produto. }\end{array}$ & $\begin{array}{l}\text { Não, se não é culpa dela, ela deveria só } \\
\text { mandar o contato da outra empresa } \\
\text { para resolver o problema. }\end{array}$ & Feliz ela não ficou, mas não ficou puta. & $\begin{array}{l}\text { Depende do produto que ela fosse } \\
\text { comprar. Se for um produto que queria } \\
\text { de imediato não, mas se puder esperar } \\
\text { acho que poderia dar mais uma chance. }\end{array}$ \\
\hline $\mathrm{H}$ & 8 & 25 & Estudante & $\begin{array}{l}\text { Acho péssima solução, porque a partir } \\
\text { do momento que você coloca seu nome, } \\
\text { você é responsável por aquilo. }\end{array}$ & $\begin{array}{l}\text { Sim, no mínimo, ela que deveria fazer o } \\
\text { contato com a empresa menor e saber } \\
\text { o que houve com o produto. }\end{array}$ & $\begin{array}{l}\text { Obviamente não ficou feliz com a } \\
\text { solução, ele já não estava feliz antes } \\
\text { quando o produto não chegou. }\end{array}$ & Não e com certeza não fará. \\
\hline $\mathrm{H}$ & 9 & 28 & Advogado & $\begin{array}{l}\text { Um absurdo! As empresas marketplace } \\
\text { só querem o bônus e não o ônus. }\end{array}$ & $\begin{array}{l}\text { Óbvio. Deveria se mostrar mais } \\
\text { preocupada com o que aconteceu com } \\
\text { uma abordagem mais amigável. "Você } \\
\text { pode entrar em contato clicando nesse } \\
\text { link, mas se não te responderem em X } \\
\text { tempo você responde esse e-mail que } \\
\text { entraremos em contato internamente". }\end{array}$ & $\begin{array}{l}\text { Não, porque ele esperava um } \\
\text { liquidificador rápido e não esperava ser } \\
\text { tratato assim. Porque ele comprou no } \\
\text { site da loja, mesmo sendo marketplace. }\end{array}$ & Não. \\
\hline $\mathrm{H}$ & 10 & 22 & Estudante & $\begin{array}{l}\text { Para mim é inviável, quando eu to } \\
\text { comprando no maketplace, a empresa } \\
\text { que eu to comprando que tem que ter } \\
\text { essa preocupação. Acho inexplicável } \\
\text { essa situação. }\end{array}$ & $\begin{array}{l}\text { Sim, totalmente. Tem que pedir } \\
\text { desculpas, entender o que estar } \\
\text { acontecendo, entrar em contato com a } \\
\text { loja que fez a venda e qualquer } \\
\text { problema eles tinham que solucionar } \\
\text { rápido. Além disso, dar um retorno } \\
\text { agradável ao cliente: informar o ocorrido } \\
\text { e oferecer alternativas como produtos } \\
\text { similares. }\end{array}$ & $\begin{array}{l}\text { Claro que não. Indignado procurando } \\
\text { PROCON. }\end{array}$ & $\begin{array}{l}\text { Eu não voltaria, não gosto dessa } \\
\text { situação e achei muito ruim a situação. } \\
\text { Só se fosse muito necessário. }\end{array}$ \\
\hline $\mathrm{H}$ & 11 & 23 & Professor & $\begin{array}{l}\text { Ruim por dar ao Marcelo um segundo } \\
\text { trabalho. Se eles oferecem o produto de } \\
\text { outra empresa, eles também são } \\
\text { responsáveis. }\end{array}$ & $\begin{array}{l}\text { Tentar entrar em contato com a } \\
\text { empresa ou ver se tinha uma solução } \\
\text { que dimuisse o tempo de espera. }\end{array}$ & Não, porque deu mais trabalho pra ele. & $\begin{array}{l}\text { Se diminuísse o tempo de espera ou se } \\
\text { for solucionado após o contato da outra } \\
\text { empresa, poderia voltar sim. }\end{array}$ \\
\hline $\mathrm{H}$ & 12 & 24 & Administra & $\begin{array}{l}\text { Ruim, porque a empresa tem que se } \\
\text { responsabilizar por quem coloca no } \\
\text { a marketplace dela. }\end{array}$ & $\begin{array}{l}\text { Ela poderia ter assumido o papel de ser } \\
\text { a intermediária da situação e depois } \\
\text { reavaliar o fornecedor. }\end{array}$ & $\begin{array}{l}\text { Com certeza, não. É como se tivesse } \\
\text { de jogando pra vários lados. }\end{array}$ & $\begin{array}{l}\text { Não, sinceramente, não. Porque esse é } \\
\text { um caso que se aconteceu pra um } \\
\text { fornecedor, é politica da empresa } \\
\text { mandar tratar assim esse caso. }\end{array}$ \\
\hline
\end{tabular}

